\title{
Infiltration of Rhodamin B into three materials used as cervical barrier
}

\author{
Infiltração da Rodamina B em três materiais utilizados como tampão cervical
}

Grazielle Morais de SOUZA'

Luis Cardoso RASQUIN ${ }^{1}$

Fabíola Bastos de CARVALHO'

\section{ABSTRACT}

\section{Objective}

To evaluate in vitro the sealing ability of three materials used as cervical barrier for internal dental bleaching.

\section{Methods}

Thirty-threecanines wereselected, and afterbiomechanical rootcanalpreparation, thecanalswerefilled bylateralcondensation technique. After the filling material setting reaction, the teeth were randomly divided into three groups of ten teeth each, according to the following materials for constructing the cervical barrier: X Temp LC; Vitro Fil; Coltosol. The control group consisted of three teeth, without placement of the cervical cap. Sodium perborate /distilled water associated with $2 \%$ Rhodamin B were used as bleaching substance. After placing the bleaching agent in the pulp chamber, access cavities were sealed with temporary cement IRM and samples were stored at $37^{\circ}$ for 7 days. After this period, the samples were cleaved longitudinally, and leakage was evaluated by the visual method. The data were submitted to Pearson test with a 5\% level of significance.

\section{Results}

No statistically significant difference was found between the study groups, however, the largest number of specimens with a lower degree of leakage were found in the Coltosol group.

\section{Conclusion}

All the materials evaluated for making the cervical cap allowed some level of leakage.

Indexing terms: Nonvital tooth. Tooth bleaching. Tooth resorption.

\section{RESUMO}

Objetivo

Avaliar in vitro a capacidade seladora de três materiais utilizados como barreira cervical durante o clareamento interno.

\section{Métodos}

Foram selecionados trinta e três caninos humanos, que após o preparo biomecânico dos canais radiculares, foram obturados pela técnica da condensação lateral ativa. Após a reação de presa do material obturador os dentes foram divididos aleatoriamente em três grupos de dez dentes cada, de acordo com os seguintes materiais para confecção da barreira cervical: X Temp LC; Vitro Fil; Coltosol. O grupo controle constituiu de três dentes sem a confecção do tampão cervical. Utilizou-se como substância clareadora o Perborato de Sódio/ água destilada associado à Rodamina B 2\%. Após a colocação do agente clareador na câmara pulpar, as aberturas coronárias foram seladas com cimento provisório IRM e as amostras foram armazenadas em estufa a $37^{\circ}$ por 7 dias. Após esse período, as amostras foram clivadas no sentido longitudinal, e a avaliação da infiltração foi realizada pelo método visual. Os dados foram submetidos ao teste estatístico de Kruskal-Wallis, com nível de significância de $5 \%$.

\section{Resultados}

Não houve diferença estatisticamente significante entre os grupos de estudo, embora o Coltosol tenha obtido maior número de espécimes com menor grau de infiltração.

\section{Conclusão}

Todos os materiais avaliados na confecção do tampão cervical permitiram algum nível de infiltração.

Termos de indexação: Dente não vital. Clareamento dental. Reabsorção de dente.

\footnotetext{
${ }^{1}$ Universidade Federal da Bahia, Faculdade de Odontologia. Av. Araújo Pinho, 62, Canela, 40110-150, Salvador, BA, Brasil. Correspondência para / Correspondence to: FB CARVALHO.E-mail: <fabiolabcarvalho@ig.com.br>.
} 


\section{INTRODUCTION}

Frequently, the teeth are a source of personal dissatisfaction, and color change is one of the reasons for seeking dental treatment ${ }^{1}$. This is why tooth bleaching is one of the most sought-after esthetic treatments in dental offices $^{2}$.

Tooth bleaching techniques have become very popular and their precise purpose is to fulfill the desire for improved esthetic appearance, so highly appreciated nowadays. For this purpose, different types and concentrations of chemical agents are used, which must at all times be applied under the control and supervision of the dentist

Non vital tooth bleaching is a conservative and esthetic alternative in the treatment of teeth darkened after endodontic treatment, offering greater preservation of tooth structure, at low cost when compared with more invasive procedures, such as fabrication of veneers or total crowns, restorative maneuvers or even the association of restorative and bleaching techniques ${ }^{3-9}$.

Color changes in non vital teeth may occur due to a series of etiological factors, such as the occurrence of pulp hemorrhage caused by traumatisms; after pulpotomy or pulpectomy, in which the rupture of blood vessels allows penetration of erythrocytes into the dentinal tubules, and their hemolysis releasing hemoglobin; inadequate coronal access, with the permanence of areas of retention such as the roof; penetration product resulting from pulp tissue decomposition into the dentinal tubules; the presence of filling material remainders in the root canal, and medications used in endodontic treatment in the pulp chamber ${ }^{4-9}$. Loguercio et al. ${ }^{3}$ affirmed that irrespective of the causal factors, all professionals must be well prepared to correctly diagnose the cause of color changes, because this is an indispensable condition for successful bleaching treatment.

For whitening endodontically treated teeth, hydrogen and carbamide peroxides, and sodium perborate may be used as bleaching agents. These have similar mechanisms of action, because both carbamide peroxide and sodium perborate degrade into hydrogen peroxide, which in turn decomposes into water and nascent oxygen ${ }^{10}$

Some side effects have been observed after internal bleaching, and compromise of tooth strength, possibility of recurrence of darkening and external root resorption are pointed out ${ }^{11-12}$. One hypothesis is that the bleaching agent completely penetrates into the dentinal tubules in the direction towards the periodontal ligament, and starts an inflammatory reaction, resulting in external root resorption ${ }^{1,11}$. Another hypothesis is the occurrence of dentinal denaturing by the bleaching agent, at the amelocement junction 3,13 .

Failures or absence of the enamel-cement junction are predisposing factors for the development of cervical resorption, since the bleaching substance will have free access to periodontal tissue, causing an inflammatory reaction in the tissues. These defects may present in approximately $25 \%$ of the population $1,5,11,14$. Souza et $a{ }^{13}$, in their study, demonstrated that diffusion of hydrogen peroxide into the cervical third was two times higher in teeth in which the cement had intentionally been removed. Rodrigues et al. ${ }^{1}$ affirmed that there is no possibility whatever of clinically predicting the existence and locations of micro-exposures of dentin along the amelocement by means of the present means of analyses. This includes analysis by means of radiographic images, and the possibility of any tooth presenting exposed dentin in the cervical region must be considered.

Therefore, the construction of a cap at the root canal entrance is recommended, in order to seal the amelocement region. Various materials have been used for constructing the cervical cap, among them polycarboxylate cement, glass ionomer cement, zinc phosphate cement, resin cement, among others may be mentioned, at all times seeking a material that promotes the best sealing of the cervical region? ${ }^{9}$.

The sealing capacity of these restorative materials used as cervical barrier may be harmed by both the bleaching agent and the type of material used ${ }^{15}$. Different methods are used for evaluating marginal leakage of restorative materials, such a penetrant dyes ${ }^{16-17}$, transport of fluids ${ }^{15}$ and microbiological tests ${ }^{18}$.

Rhodamin B dye has been used in various studies 16-17,19-20 for evaluating marginal leakage of restorative materials, because it has homogeneity and stability when in contact with other materials, and does not undergo discoloration.

The aim of this study was to evaluate the sealing capacity, by means of infiltration with $2 \%$ Rhodamin $B$, of three materials used as cervical cap during endogenous bleaching (X Temp LC, DFL, Rio de Janeiro, Brazil; Vitro Fil - DFL, Rio de Janeiro, Brazil; Coltosol, Vigodent, Rio de Janeiro, Brazil), in endodontically treated teeth. 


\section{METHODS}

For this study, thirty-three extracted human canine teeth, obtained from the Surgery I course of the Dental School, Federal University of Bahia, were selected. They were stored in a $1 \%$ Thymol solution, in a refrigerator. (This study was approved by the Research Ethics Committee of this institution, under Protocol CAAE: 0009.0/368,000-11). The samples were washed in running water before being used. After this periapical radiographs were taken in the vestibular-lingual and mesial-distal directions, to evaluate possible calcifications in the pulp chamber and root canal.

Coronal opening was performed with a spherical carbide bur, and afterwards the odontometry was determined by the visual method, in which a K file No.10 (DentsplyMaillefer, Ballaigues, Switzerland) was introduced into the root canal until it was visualized in the apical foramen. After this, it was withdrawn $1 \mathrm{~mm}$, establishing the real working length (RWL) at $1 \mathrm{~mm}$ from the apical foramen.

For biomechanical preparation, the serial technique with anatomical scaling was performed. Initially, a K 25 type file was chosen (Dentsply-Maillefer, Ballaigues, Switzerland) and was adjusted to the RWL. This, and another three instruments in the sequence were subsequently used up to the RWL to make the apical stop. Anatomic scaling was performed with the use of another 5 instruments in the sequence, concluding with a K 70 type file (Dentsply-Maillefer, Ballaigues, Switzerland).

During root canal preparation $1 \mathrm{ml}$ of $1 \%$ sodium hypochlorite, Milton Solution (Biodinâmica, Ibiporã, Brazil) associated with Endo-PTC (Biodinâmica, Ibiporã, Brazil) were used as auxiliary substances of instrumentation, at every change of instrument. To remove the smear layer, the canals were filled with $0.1 \mathrm{ml}$ of 17\% EDTA (Biodinâmica, Ibiporã, PR, Brazil) for 3 minutes, and subsequently irrigated with $1 \mathrm{ml}$ of $1 \%$ Sodium hypochlorite, Milton Solution (Biodinâmica, Ibiporã, Brazil). Final washing was performed with $0.5 \mathrm{ml}$ of anionic detergent, Tergensol (Inodon, Porto Alegre, Brazil). These substances were inserted in the root canal with the aid of a disposable syringe, and removed with an aspiration cannula.

The canals were dried with absorbent paper cones, according to the last file used at the RWL.

After root canal preparation, filling was performed with calibrated gutta-percha (Dentsply-Maillefer, Ballaigues, Switzerland) and zinc oxide and eugenol-based cement (Endofill, Dentsply, Petrópolis, Brazil), by the active lateral condensation technique. A small portion of cotton wool was place in the entrance of the root canal and the coronal opening was restored with provisional zinc oxide and eugenol-based cement (IRM, Dentsply, Petrópolis, Brazil). The samples were kept in a biologic oven at $37^{\circ} \mathrm{C}$, with $100 \%$ humidity for 7 days for the setting reaction of the filling material to occur. After this period, the provisional cement was removed with thee aid of a diamond-coated spherical bur, 1014 (KG Sorensen Ltda., São Paulo, Brazil) and with the aid of a heated Paiva shim, approximately $2 \mathrm{~mm}$ of the root canal filling was removed to construct the cervical cap. This length was verified with a millimetric periodontal probe. Before constructing the cervical cap, the pulp chamber was irrigated with 17\% ETDA (Biodinâmica, Ibiporã, Brazil) for 3 minutes, with the purpose of removing the inorganic portion of the smear layer. After this, the pulp chamber was dried with cotton wool.

The specimens were randomly divided into 3 experimental groups of 10 teeth in each, according to the material used to make the cervical cap. Group 1 - chemical setting glass ionomer cement - Vitro Fil (DFL, Rio de Janeiro, Brazil); Group 2 - Coltosol - cement set by hydration - (Vigodent, Rio de Janeiro, Brazil); and Group 3 - X Temp LC - Light polymerizable provisional cement (DFL, Rio de Janeiro, Brazil).

The materials used for making the cervical caps were manipulated in accordance with the respective manufacturers' recommendations. The glass ionomer cement was applied with a Centrix syringe, in order to reduce bubble formation. In Group 2, after making the cervical cap, a small portion of cotton wool damped with water was inserted in the pulp chamber to help the setting reaction of Coltosol to occur. A period of 1 day, during which time the specimens were kept in the biological oven, was waited for the setting reaction of the cement in Groups 1 and 2 to occur.

The bleaching agent applied was Sodium Perborate (Whiteness Perborato, FGM, Joinvile, Brazil), which was manipulated with distilled water, in accordance with the manufacturer's instructions. In order to evaluate the sealing capacity, $0.01 \mathrm{ml}$ of 2\% Rhodamin coloring agent was associated with the bleaching agent. After inserting the bleaching agent in the pulp chamber, impermeable paper was put into place to separate the bleaching agent from the IRM provisional cement (Dentsply, Petrópolis, Brazil), used to seal the coronal opening. After this, the samples were then stored in a biological oven at a temperature of $37^{\circ} \mathrm{C}$ for 7 days.

In the control group, the bleaching agent was deposited without making a cervical cap.

After the 7-day period had elapsed, the provisional sealing was removed with the use of a diamond-coated 
spherical bur 1014 (KG Sorensen Ltda., São Paulo, Brazil) and the bleaching agent removed by washing with physiological solution. The samples were sectioned longitudinally with a diamond-coated disc, and evaluated under a stereoscopic loupe STEMI DV (Carl Zeiss, Germany) to determine the degree of dye leakage.

For this evaluation, the following scores were used: 0 (zero) for no leakage at the cap; 1 (one) leakage up to half the total length of the cap; 2 (two) leakage to over half the total length of the cervical cap. Statistical analysis was performed at a $5 \%$ level of significance.

\section{RESULTS}

After determining the score of each tooth, with the aid of a stereoscopic loupe STEMI DV (Carl Zeiss, Germany), the data were statistically analyzed using the software program BioEstat 5.3. The Groups were compared 2 by 2 , using the non parametric Chi-square test.

The scores found for each specimen are described in Table 1. In Figure 1, the percentage distribution of the test specimens, evaluated according to the degree of leakage may be analyzed.

Table 1. Dye Leakage Scores in each Specimen Salvador (BA), 2011.

\begin{tabular}{lcccccccccc}
\hline Material & Tooth & Tooth & Tooth & Tooth & Tooth & Tooth & $\begin{array}{c}\text { Tooth } \\
7\end{array}$ & $\begin{array}{c}\text { Tooth } \\
8\end{array}$ & $\begin{array}{c}\text { Tooth } \\
9\end{array}$ & $\begin{array}{c}\text { Tooth } \\
10\end{array}$ \\
\hline Control & 1 & 2 & 3 & 4 & 5 & 6 & & & \\
Vitro Fil & 2 & 2 & 2 & & & & & & \\
X Temp LC & 1 & 0 & 0 & 1 & 0 & 1 & 0 & 0 & 1 \\
Coltosol & 2 & 1 & 0 & 0 & 0 & 0 & 2 & 1 & 2 & 0 \\
\hline
\end{tabular}

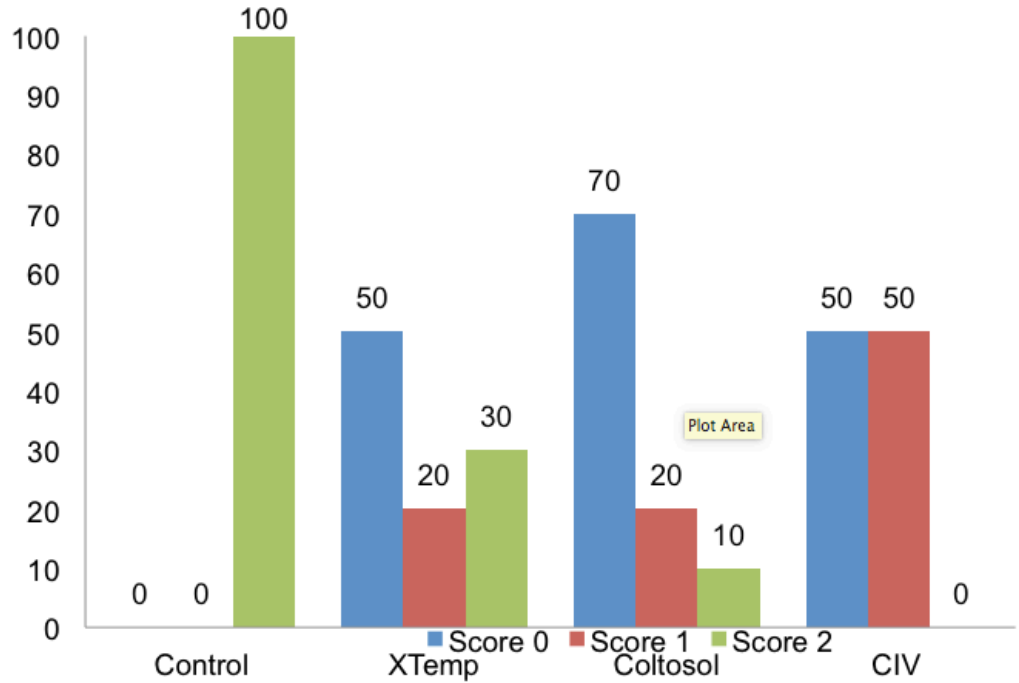

Figure 1. Distribution of leakage according to groups evaluated. Salvador (BA), 2011.

Statistical difference between all the groups was observed when compared with the control group $(p<0.05)$. The three specimens presented total dye leakage.

For Group 2 (Coltosol) 70\% of the specimens were observed to present score zero of leakage. Group 1 (Vitro Fil) presented the second best result, with specimens showing 0 and 1 scores of leakage, followed by Group 3 (X Temp LC) in which the specimens presented 0, 1 and 2 scores.

Although the Coltosol Group was the one with the lowest degree of leakage, no statistically significant differences $(p>0,05)$ were observed between the groups, as may be observed in Table 2 .

Table 2. Statistical analysis: intergroup comparison. Salvador (BA), 2011.

\begin{tabular}{lc}
\hline Groups & P-value \\
\hline Control x XTemp LC & $<0.05$ \\
Control x Coltosol & $<0.05$ \\
Control x Vitro Fil & $<0.05$ \\
XTemp LC X Coltosol & $0.64^{\star}$ \\
X Temp LC X Vitro Fil & $0.34^{\star}$ \\
Coltosol x Vitro Fil & $0.16 *$ \\
\hline
\end{tabular}

${ }^{*} \mathrm{p}>0.05$ 


\section{DISCUSSION}

Although internal bleaching presents advantages, this may trigger harmful effects, such a reduction in fracture strength, denaturation of the dentin and cement, recurrence of staining and occurrence of external cervical resorption ${ }^{11-12}$.

The $\mathrm{pH}$ on the root surface is reduced after the use of endogenous bleaching agents. This acid medium appears to contribute to osteoclastic activity that will result in root resorption ${ }^{21}$. The lack of bond between the cement and enamel is a predisposing factor for the occurrence of external cervical resorption after endogenous bleaching, since it favors penetration of bleaching agents during the treatment ${ }^{1,3,5,9}$.

The construction of a barrier in the cervical region is recommended, in an endeavor to prevent or minimize the passage of bleaching agents in the direction towards the external cervical and tooth root apical regions. This procedure would also protect the dentinal tubules located close to the gingival attachment, and protect the filling treatment previously performed ${ }^{3,5,8-9,}$,

Among the materials studies, Coltosol is a hygroscopic material that sets with exposure to humidity, and has a high degree of linear expansion. This is because it contains calcium sulphate hemihydrate plaster in its composition, in addition to other substances, such as zinc oxide, hydrate zinc sulphate, diatomaceous earth, dibutyl phthalate, polyvinyl chloride copolymer ${ }^{22}$. It does not require manipulation, thereby facilitating professional use, however, ideally it should be used hours before the bleaching procedure, which involves having another clinical session. In this study, in Group 2 (Coltosol), a small portion of damp cotton wool was placed in the pulp chamber and a period of 24 hours was waited for the cement to set,

XTempLC is a light activated resin material that does not require previous conditioning, and as is the case with Coltosol, it has the advantage of its working time being controlled by the professional. Vitro Fil is an ionomer cement that shows good bond to dental structures, however, it has the disadvantage of a high degree of solubility and technical sensitivity in the stages of manipulation and post-insertion. For application of the cement, the use of a Centrix syringe is the most indicated technique, as it facilitates insertion ${ }^{25}$. In the present study, a Centrix syringe was used to make the cervical cap with ionomer cement, in an attempt to reduce bubble formation, which could contribute to a higher degree of bleaching agent leakage.
In this research, the control group presented total leakage of the dye by virtue of absence of a cervical cap, a fact also confirmed by Gomes et al., ${ }^{23}$. This finding was in disagreement with the study of Vasconcellos et al. ${ }^{26}$ who observed significant results for the Control Group. In this group, only $1 \mathrm{~mm}$ of gutta percha was removed, without making a cervical cap; that is, the root canal filling material itself was responsible for sealing. In approximately $75 \%$ of the test specimens there was no leakage, when compared with resin cement, resin modified glass ionomer cement and zinc phosphate cement.

Although the presence of the cervical cap was not sufficient to prevent leakage in all the specimens of the groups evaluated, there was statistically significant difference between the control group and other groups. Thus, demonstrating the real need for cervical sealing, with the purpose of preventing resorptions and future tooth losses.

There was no statistical difference among the groups tested. However, Group 2 (Coltosol) presented the largest number of specimens with the lowest dye leakage scores. This result is compatible with that of the study of Gomes et al. ${ }^{23}$ who observed the better efficacy of Coltosol in comparison with glass ionomer. Group 1 (Vitro Fil) presented the second best performance, corroborating the study of Pinto et al., ${ }^{27}$ who observed a lower degree of leakage of glass ionomer cement in comparison with the resin material (flow resin - DFL).

Whereas, Vasconcelos et al. ${ }^{26}$ showed evidence of better sealing of the resin cement Sealer 26, in this case used to make the cervical cap, in comparison with glass ionomer. This is in disagreement with our findings, because the group that received the resin material as cervical cap, presented a higher degree of leakage than the glass ionomer cement. This result may be as a result of the increase in bond strength to dentin of the glass ionomer, due to prior etching of the dentin surface with ETDA $^{28}$. In the case of resin materials, it is known that rupture may occur at the tooth/resin interface, due to polymerization shrinkage.

For Garzón et al. ${ }^{29}$ a reduction in microleakage can still be achieved if the cervical cap is made one week after endodontic treatment. In this study, the cervical cap was made 7 days after filling the root canals.

Although Coltosol presented better results than Vitro Fil and X Temp LC, it was observed that all the sealing materials allowed dye leakage, however, when 
the barrier was not made, it involved total leakage of the bleaching agents. To minimize the effects of these agents, the use of less caustic materials is recommended, in addition to the use of a calcium hydroxide-based delayed dressing after the bleaching sessions, in an endeavor to revert the drop in Ph caused by the bleaching substance ${ }^{27}$.

\section{REFERENCES}

1. Rodrigues E, Panzarini SR, Pedrini D. Clareamento dentário após traumatismo dento - alveolar. RGO, Rev Gaúch Odontol. 2006;54(4):379-83.

2. Sacono N, Coldebella CR, Ribeiro APD, Soares DGS, Trindade FZ, Hebling J, et al. Efeito citotóxico de agentes clareadores a base de peróxido de hidrogênio a $20 \%$ e $38 \%$ sobre células odontoblastóides. Rev Odontol Bras Central. 2010;18(48):15-21.

3. Loguercio AD, Souza D, Floor AS, Mesko M, Barbosa NA, Busato ALS. Avaliação clínica de reabsorção radicular externa em dentes desvitalizados submetidos ao clareamento. Pesq Odontol Bras. 2002;16(2):131-5

4. Martins JD, Bastos LC, Gaglianone LA, Azevedo JFGD, Bezerra $\mathrm{RB}$, Morais PMR. Diferentes alternativas de clareamento para dentes escurecidos tratados endodonticamente. Rev Cienc Méd Biol. 2009;8(2):213-8

5. Bernardineli N, Bodanezi A, Bramante CM, Garcia RB, Moraes IG. Influência da morfologia da junção amelocementária (JAC) nas alterações de $\mathrm{pH}$ extrarradicular associadas ao clareamento intracoronário. Rev Odontol UNESP. 2009;38(5):286-90.

6. Erhardt Mc, Shinohara M, Pimenta LA. Clareamento dental interno. RGO, Rev Gaúch Odontol. 2003;51(1):23-9.

7. Macedo A, Vidal A, Duarte D. Clareamento dental em dentes decíduos RFO - UPF. 2007;12(2):74-8

8. Dezotti M, Souza Júnior MH, Nishiyama CK. Avaliação da variação de $\mathrm{pH}$ e da permeabilidade da dentina cervical em dentes submetidos ao tratamento clareador. Pesqui Odontol Bras. 2002:16(3):263-8 doi: 10.1590/\$1517-74912002000300014

9. Cardoso RM, Melo Júnior PC, Gomes GL, Souza FB, Silva CHV. Avaliação radiográfica de tampões cervicais no clareamento endógeno. RGO, Rev Gaúch Odontol. 2006;54(3):280-3.

10. Leonardo M. Endodontia: tratamento de canais radiculares - princípios técnicos e biológicos. São Paulo: Editora Artes Médicas; 2005.

11. Britto J, Holland R, Junior E. Clareamento de dentes escurecidos: influência do tipo de veículo empregado com o perborato de sódio. RGO, Rev Gaúch Odontol. 2000;48(2):97-101.

12. Silva EM, Leonardi DP, Haragushiku GA, Tomazinho FSF, Filho FB, Zlelak JC. Etiologia e prevenção das reabsorções cervicais externas associadas ao clareamento dentário. Rev Sul-Bras Odontol. 2010;7(1):78-89.

\section{CONCLUSION}

After analysis of the results, it could be concluded that all the materials tested presented dye leakage, in the following increasing order of leakage: Coltosol, Vitro Fil and X Temp LC, although this difference was not statistically significant.

13. Souza A, Gavini G, Bertotti M. Avaliação in vitro da difusão do peróxido de hidrogênio e do hidróxido de cálcio durante o clareamento intra-coronário. Endod Clin Pract Educ. 1999;1(1).

14. Louro RL, Almeida SA, Nogueira LC, Pazolini P, Ceschim MA, Pereira J. Prevenção de reabsorção cervical no clareamento em dentes despolpados: relato de caso clínico. UFES Rev Odont. 2008;10(1):49-56

15. Canoglu E, Gulsahi K, Sahin C, Altundasar E, Cehreli ZC. Effect of bleaching agents on sealing properties of different intraorifice barriersand root filling materials. Med Oral Patol Oral Cir Bucal. 2012;17(4):710-5. doi:10.4317/medoral.17751

16. Post LK, Lima FG, Xavier CB, Demarco FF, Gerhardt-Oliveira $M$. Sealing ability of MTA and amalgam in different root-end preparations and resection bevel angles: an in vitro evaluation using marginal dye leakage. Braz Dent J. 2010;21(5):416-419. doi: 10.1590/s0103-64402010000500007

17. Corona SAM, Borsatto MC, Rocha RASS, Palma-Dibb RG. Microleakage on Class V Glass lonomer Restorations After Cavity Preparation with Aluminum Oxide Air Abrasion. Braz Dent J. 2005;16(1):35-8. doi: 10.1590/S0103-64402005000100006

18. Chailertvanitkul P, Abbott PV, Riley TV, Sooksuntisakooncha $\mathrm{N}$. Bacterial and dye penetration through interim restorations used during endodontic treatment of molar teeth. J Endod. 2009;35(7):1017-22. doi: 10.1016/j.joen.2009.04.019

19. Orosco FA, Bramante CM, Garcia RB, Bernardineli N, Moraes IG. Sealing ability, marginal adaptation and their correlation using three root-end filling materials as apical plugs. I Appl Oral Sci. 2010;18(2):127-34. doi: 10.1590/S167877572010000200006

20. Oliveira MG, Primo BT, Silva DL, Pozza DH, Marzola C. Análise de duas metodologias na aferição de infiltração por corante em apicoplastias com retro-obturações. RFO - UPE. 2010;15(2):160-4.

21. Vosoughhosseini S, Lotfi M, Shahmoradi K, Saghiri MA, Zand $\mathrm{V}$, Mehdipour $\mathrm{M}$, et al. Microleakage comparison of glassionomer and white mineral trioxide aggregate used as a coronal barrier in nonvital bleaching. Med Oral Patol Oral Cir Bucal. 2011;16(7): ):e1017-21. doi:10.4317/medoral.17306

22. Gomes GLS, Melo Júnior PC, Cardoso RM, Souza FB, Silva CHV. Capacidade seladora de tampões cervicais. Odontol Clín-Científ. 2007;6(2):139-42

23. Gomes MEO, Ribeiro BCL, Yoshinar GHI, Pereira KFS, Gonçalves JB, Candido MSM. Análise da eficácia de diferentes materiais utilizados como barreira cervical em clareamento endógeno. RGO, Rev Gaúch Odontol. 2008;56(3):275-9. 
24. Yui $\mathrm{KC}$, Kubo $\mathrm{CH}$, Assis NMSP, Gomes APM, Balducci I. Influência de agentes clareadores no tampão cervical realizado com cimento de ionômero de vidro modificado por resina. Cienc Odontol Bras. 2004;7(3):60-6.

25. Fook ACBM, Azevedo VVC, Barbosa WPF, Fidéles TB, Fook MVL. Materiais odontológicos: cimentos de ionômero de vidro. Rev Eletr Mat Proc. 2008;3(1):40-5.

26. Vasconcelos W, Assis B, Albuquerque R. Avaliação da capacidade de vedamento da região cervical por materiais usados na confecção do tampão durante o clareamento dental endógeno. Biol Health Sci. 2000;6:29-42.

27. Pinto CA, Moreira TV, Zõliner NA, Hein LRO, Medeiros JMF, Almeida ETDC. Eficiência de algumas barreiras cervicais utilizadas durante o clareamento interno. Rev Bras Odontol. 2006;63(3/4):220-4.
28. Craig R, Powers J. Materiais dentários restauradores. São Paulo: Editora Santos; 2004.

29. Garzón HR, Pérez MPP, Monedero A, Velásquez EV. Estudio piloto de microfiltración in vitro de dos materiales selladores para blanqueamiento en dientes no vitales. Rev Estomatología. 2006;14(1):22-6.
Received on: 8/3/2013

Final version resubmitted on: 6/2/2014

Approved on: 20/3/2014 
